\title{
Applying Refugee Family Reunion Law Therapeutically
}

\author{
Katy Ferris $^{1 *}\left(\mathbb{0}\right.$, James Marson $^{2}$, Anna Kawalek ${ }^{3}$ \\ ${ }^{1}$ Nottingham University Business School, Jubilee Campus, Nottingham, UK \\ ${ }^{2}$ Department of Law and Criminology, Law Sheffield Hallam University, Collegiate Crescent, Collegiate Campus, Sheffield, UK \\ ${ }^{3}$ Leeds Law School, Law Leeds Beckett University, City Campus, Leeds, UK \\ Email: *Katy.Ferris@nottingham ac.uk
}

How to cite this paper: Ferris, K., Marson, J., \& Kawalek, A. (2019). Applying Refugee Family Reunion Law Therapeutically. Beijing Law Review, 10, 1172-1196. https://doi.org/10.4236/blr.2019.105062

Received: July 5, 2019

Accepted: October 11, 2019

Published: October 14, 2019

Copyright (c) 2019 by author(s) and Scientific Research Publishing Inc. This work is licensed under the Creative Commons Attribution International License (CC BY 4.0).

http://creativecommons.org/licenses/by/4.0/ (c) (†) Open Access

\begin{abstract}
This paper aims to highlight some of the key issues surrounding the development and application of immigration law as it applies in the United Kingdom (UK) to refugees attempting to be reunited with their families living abroad. The right for refugees to be reunited with their families is enshrined in international law, but this is frequently frustrated by the legal and administrative systems used in the UK. Using content analysis and doctrinal analysis techniques, the paper provides an examination of how a philosophy which considers the emotional effects of the law, therapeutic jurisprudence, could be used not only to inform interpretation of current domestic laws, but also influence the drafting of future legislation. This is an aspect of current refugee law in the United Kingdom which has yet to be examined. It provides, we argue, a humanitarian direction to statutory interpretation which may provide tangible benefits to current and proposed legal systems.
\end{abstract}

\section{Keywords}

Refugees, Family Reunion, Therapeutic Jurisprudence, Purposive

Interpretation, Refugee (Family Reunion) Bill

\section{Introduction}

"Refugees run multiple risks in the process of fleeing from persecution, one of which is the very real risk of separation from their families." (Jastram \& Newland, 2003: p. 555)

Legislation, both international and domestic, regulates the mechanism for refugees to be reunited with their families. Whilst recognised as a human right and a fundamental requirement in several international treaties and conven- 
tions, it is subject to numerous limitations and exemptions in domestic law. A tension exists between the rights of individuals to be able to be joined with their family to start their new life in a "safe" country, with State desires to regulate immigration and protect against abuse of the system. A potential resolution to some of the most contentious differences is being considered by the UK Parliament. However, as immigration legislation has become a battleground for political disagreements, and faced with legislative inertia surrounding the British exit of the European Union, this may be unfulfilled.

This paper is concerned with the rights of individuals who reside in the UK as a refugee. ${ }^{1}$ Having been designated a refugee, the individual is unable to reside in their home country due to fear of persecution or a lack of safety due to conflict. Such individuals have a right, enshrined in international and national law, to be reunited with their (nuclear and pre-flight) families living abroad. ${ }^{2}$ This right is exercised through an application procedure and one which, at least according to the government, ${ }^{3}$ is straightforward and sufficiently accessible as to not require free legal assistance. The reality, however, as substantiated through several reports demonstrates a system fraught with difficulties and practical obstacles which can prevent the reunification of the refugee with their disunited spouse and children. ${ }^{4}$ Beyond the practical problems including language and cultural barriers (Pereira et al., 2012), limited IT skills and obstacles around Western constructs of, for example, celebrating and registering births and the collection, collation and maintenance of supporting documents, refugees have already experienced significant disruption to their lives. They have been separated from their families, they frequently display signs of distress and mistrust of organisations and personnel in authoritative positions, and recent research has identified that all refugees suffer some element of post-traumatic stress (Goodman et al., 2017). Such trauma is found from the above circumstances but also poverty (Fortuny, Hernandez, \& Chaudry, 2010), problems accessing services (Yoshikawa, Godfrey, \& Rivera, 2008), the circumstances surrounding the processing of immigration claims (Letiecq et al., 2014), and the uncertainty surrounding the refugees' future treatment (Schumm et al., 2005). These issues create practical problems which, understandably, have significant psychological and anti-therapeutic effects on the parties concerned. They are also subject to legal systems which exist to facilitate remedies for breaches of substance and procedure.

\footnotetext{
${ }^{1}$ An individual may arrive in the UK with refugee status through the Gateway or Protection programmes. Typically, the individual arrives in the UK, claims asylum and may or may not be granted refugee status or humanitarian protection for five years. This may be granted on the basis of first tier decision making or granted post a tribunal hearing.

${ }^{2}$ In country applications are also possible where the family members already reside in the UK, although these applications are subject to different applications (and is a paid route, rather than free as per refugee family reunion).

${ }^{3}$ Hansard, 29 November 2016, Vol. 617, Column 539WH. Available:

https://hansard.parliament.uk/commons/2016-11-29/debates/16112935000003/RefugeeFamilyReunion

(ImmigrationRules) (accessed 1 July 2019).

${ }^{4}$ See for instance UNICEF (2016) Available:

https://downloads.unicef.org.uk/wp-content/uploads/2017/09/Unicef TheRefugeOfFamily briefing.pdf

(accessed 1 July 2019); Beswick (2015); and Connell et al. (2010).
} 
Resolving problems which have a justiciable solution has been the subject of profound change and evolution in recent years. If one is to consider the work of Lord Woolf and the reforms suggested following the Access to Justice report (The Right Honourable the Lord Woolf, 1996), it is evident that embedding comprehensive law approaches into legal systems has resulted in a changing philosophy (Donoghue, 2014) to be applied in these jurisdictions. ${ }^{5}$ This has been observed in many discrete legal disciplines including criminal law, family law, employment and immigration (to name but a few). For instance, creative problem-solving and specific problem-solving courts, holistic justice, preventive law and restorative justice are but some examples of movements in this area. These approaches expound issues of social justice and human rights to be values within justice systems and processes and further, should form a central component of such. These humanitarian-based approaches are beginning to become more commonplace in the UK justice system. They are unique in their aims and scope, yet they do share commonalities.

The academic literature on the subject of refugees and their movements around the world has led to the introduction and critique of many theoretical models. Among those relevant for the purpose of this paper include Castles (2011), using migration theory to explain how economic and sociological theories can be used to understand migration flows. Previous work, undertaken by organisations such as the Scottish Refugee Council (2010), report on the current state of refugee family reunion, adopting a grounded theory approach. Internationally, Boswell (2002) addresses a number of theoretical models and positions to explain migration. For example, macro theory is useful for discussing forced displacement of migrants; micro theory is used in terms of rational choice theory, and meso theory, which examines the systems and networks involved in refugee migration (see Faist, 2000), provides a discourse surrounding the causes of refugee movements. However, these theories did not address the use of law and/or the role that law and actors within the system play on those exposed to it. The authors were interested in a lens, of which we had become aware through the seminal works of Wexler and Winick (Wexler \& Winick, 1991; 1996; 2006) and Perlin, ${ }^{6}$ through which the emotional effects of the law could be viewed and assessed. Therapeutic jurisprudence (TJ) appeared to us to be the most appropriate model and an antidote to the negative effects that refugees experience, not only on the travel to the UK, but more significantly to their treatment within its legal and administrative system. ${ }^{7}$ This includes the negative psychological effects

\footnotetext{
${ }^{5}$ However, the results of the Access to Justice Report, in making the legal system less complex and more user-friendly, have not been fulfilled. See Harris (2018) Available:

https://www.thetimes.co.uk/edition/law/there-is-no-access-to-justice-if-the-public-cannot-understand-itprzdt50rn (accessed 1 July 2019).

${ }^{6}$ Perlin (1994) has written extensively on the topic but see "Therapeutic Jurisprudence: Understanding the Sanist and Pretextual Bases of Mental Disability Law”; and Perlin, Gould, \& Dorfman (1995).

${ }^{7}$ Per Inter-Governmental Consultation on Asylum, Refugee and Migration Policies in Europe, North America and Australia "Report on Family Reunification: Overview of Policies and Practices in IGC Participating States", 1997, p. 17 "Even if in most [European] States family reunification is ruled by legislative instruments, administrative regulations are often used to complete legislation with practical aspects and can result in a tougher or more favourable implementation of the law."
} 
experienced by refugees separated from their families, and the need for their well-being as a central component of their interaction with the legal and non-legal processes.

\section{Refugee Family Reunion: The Current State of the Law}

The law relating to refugee family reunion consists of both international obligations, conventions, EU legislation and national laws. Collectively they operate to provide a framework for the protection of refugees and of their rights when residing in the host state. The 1951 United Nations Convention Relating to the Status of Refugees ${ }^{8}$ along with the 1967 Protocol Relating to the Status of Refugees establish a framework for international refugee protection. ${ }^{9}$ Further, " $[t]$ he object and purpose of the 1951 Convention implies that its rights are in principle extended to the family members of refugees." ${ }^{10}$ Whilst not specifically relating to family reunion, the principle of family unity is referred to in the United Nations High Commission for Refugees (UNHCR) Handbook ${ }^{11}$ which identifies that as a minimum, the spouse and children (before reaching the age of majority) of the refugee should benefit from the provisions establishing family unity. This, specifically, relates to family life which has been disrupted due to the refugee's persecution in the home State or due to conflict making further residence in the State unsafe. The European Convention on Human Rights also ensures the rights and fundamental freedoms of individuals in the Member States. Further, since 2006 the UK has been bound by the EU Refugee Qualification Directive 2004/83/EC 12 which, at Article 23, provides for the protection of family unity and for reciprocal rights to be provided to qualifying family members in relation to State benefits. ${ }^{13}$ These provisions mirror those included in Part 11 of the Immigration Rules. The United Nations Convention on the Rights of the Child (UNCRC), at Article 3(1) obligates signatory States that "In all actions concerning children, whether undertaken by public or private social welfare institutions, courts of law, administrative authorities or legislative bodies, the best interests of the child shall be a primary consideration." Whilst a source of international law, and not incorporated into national law to the extent as is the ECHR, its relationship to ECHR Article 8 and the requirement for the teleological interpreta-

\footnotetext{
${ }^{8}$ Although the 1951 Convention is not without its critics: see Goodwin-Gill (2001), pp. 1-2: it is “... functionally inefficient, overly legalistic, complex, and difficult to apply within a world of competing [and changing] priorities ...”

${ }^{9}$ The right to family reunion arises from the 1951 Refugee Convention and is only a right given to recognised refugees who have been granted refugee status or, since October 2006, five-years limited leave to remain under the Humanitarian Protection mechanism. The right to family reunion is written into Part 8 and the relatively new FM section (Family Dependants) of the Immigration Rules (not under the Part 11 Asylum section).

${ }^{10}$ UNHCR (2001), para. 7.

${ }^{11}$ At chapter VI, paras 181-188.

${ }^{12}$ Council Directive 2004/83/EC of 29 April 2004 on minimum standards for the qualification and status of third country nationals or stateless persons as refugees or as persons who otherwise need international protection and the content of the protection granted. This Directive provides an interpretation for how the term "refugee" should be defined and how a person who is not deemed a refugee may qualify for subsidiary protection.

${ }^{13}$ Articles 24-34.
} 
tion through existing legislative sources has been recognised. ${ }^{14}$

Finally for this section briefly outlining the international regulations on refugee family reunion, the EU Dublin Regulation ${ }^{15}$ seeks to determine State responsibility for deciding asylum claims lodged in an EU Member State, in Iceland, Liechtenstein, Norway or Switzerland. The Regulation requires Member States to either maintain the close family members (spouse and children) or to bring them together when individuals seek asylum. Interestingly, and in relation to the proposed Bill ${ }^{16}$ relating to refugee family reunion, the Regulation covers unaccompanied minors and their rights to be brought together where this is in the best interests of the child. It further extends to other relatives beyond the child's parents or siblings, where these extended family members may be in a position to care for the child. A stipulation, which perhaps limits the full effect of the Regulation, is that the extended family members must be legally present in the Member State. Asylum seekers awaiting a decision on their application are, for the purposes of the Regulation, considered legally present in the Member State.

These international sources of law play an important role in enhancing the visibility and protection of refugees and their families. When national laws and legislation are read in light of these provisions, they can promote greater engagement with protective powers and facilitate a systematic interpretative approach.

\section{National Legislation}

The domestic rules and regulations governing refugee family reunion are extensive and subject to frequent change. Action by Parliament has resulted in the enactment of the Immigration and Asylum Act 1999 which established the provision for asylum support and the creation of the regulatory body (the Office of the Immigration Services Commissioner). The Nationality, Immigration and Asylum Act 2002 provides the definition of "serious criminal" (s. 72) which is used to withdraw the protection afforded to refugees. ${ }^{17}$ It also establishes the rights of appeal for refused refugee family reunion applications. The Asylum and Immigration (Treatment of Claimants) Act 2004 explains how decision-makers should apply rules regarding issues affecting an applicant's credibility, and the Borders, Citizenship and Immigration Act 2009 deals with the State's duties towards children. It introduced, at s. 55, a new duty “... to safeguard and promote the welfare of children who are in the United Kingdom.” The Immigration Act 2016 introduced new sanctions for illegal working and sought to enhance en-

\footnotetext{
${ }^{14}$ See $L D$ (Article 8 best interests of child) Zimbabwe [2010] UKUT 278. Per para. 27 "Although questions exist about the status of the UN Convention on the Rights of the Child in domestic law, we take the view that there can be little reason to doubt that the interests of the child should be a primary consideration in immigration cases."

${ }^{15}$ (EU) No. 604/2013 (sometimes referred to as the Dublin III Regulation).

${ }^{16}$ Refugees (Family Reunion) Bill [HL] 2017-19.

${ }^{17}$ Although this measure was subject to criticism by the Joint Committee on Human Rights. See House of Lords and House of Commons Joint Committee on Human Rights "The Nationality, Immigration and Asylum Act 2002 (Specification of Particularly Serious Crimes) Order 2004" (2004) Twenty-second Report of Session 2003-04, HL Paper 190, HC 1212.
} 
forcement of immigration law and to prevent "illegal migrants" from accessing services.

Beyond legislative sources, the Rules and Regulations applying to refugees exist in the Refugee or Person in Need of International Protection (Qualification) Regulations 2006, which transpose into national law aspects of the Refugee Qualification Directive 2004/83/EC. Also, in the Immigration Rules, Part 11: Asylum the procedures for determining asylum claims, the granting of leave to remain and rules relating to family reunion are contained (although provisions in Parts 8 and 9 may be relevant in certain circumstances). The main provisions relevant to refugee family reunion are as follows:

- paras 319X - 319XB set out the requirements for leave to enter the UK or to remain as the child (and under the age of 18) of a relative who has refugee status or humanitarian protection.

- paras 320 - 322 establish the grounds on which a refusal of family reunion may be made.

- paras 339A - 339AC and 339BA establish when the status of "refugee" may be revoked or renewed. Similar rules are provided for in paras 339G - 339GD for individuals granted humanitarian protection

- paras $352 \mathrm{~A}-352 \mathrm{FJ}^{18}$ identify the rules on which the granting of refugee family reunion is made. This, restrictively, is applied to the spouses and civil partners, ${ }^{19}$ unmarried/same sex partners,${ }^{20}$ of the refugee and the children (biological, adopted and de facto adopted, under the age of 18) of the refugee $^{21}$ who are "sponsored" by the refugee living in the UK.

The outcomes of the decisions made in relation to this Part of the Immigration Rules are subject to strict appeals procedures and the Immigration Act 2014 s. 15 reduced access in this regard. An appeal against a decision to refuse a human right, protection claim or a decision to revoke protected status are the grounds upon which such an appeal may be brought. The Nationality, Asylum and Immigration Act 2002 s. 82(1)(b) covers refusal of human rights claims and is based on the grounds that the decision reached is unlawful in relation to the Human Rights Act 1998 s. 6. Importantly, a refusal of an application for leave to enter or to remain in the UK on the basis of the refugee family reunion rules is considered a human rights claim for the purposes of this section of the Act.

\section{Legislative Constraints and Judicial Canutism: Problems with the Law}

As outlined above, the system of refugee family reunion is based predominately on a series of international and domestic legislative provisions applied under the

\footnotetext{
${ }^{18}$ Paragraphs 352FA, 352 FD and 352 FG of the Immigration Rules provide parallel provisions of family reunion for individuals granted humanitarian protection (on or after 30 August 2005). Individuals with humanitarian protection status are considered as refugees by the UNHCR.

${ }^{19}$ Para. 352A of the Immigration Rules.

${ }^{20} \mathrm{Para}$. 352AA of the Immigration Rules.

${ }^{21}$ Para. 352D of the Immigration Rules.
} 
overriding humanitarian principles of human rights. Before embarking on a review of the problems with the domestic law and a somewhat restrictive interpretative regime adopted in the courts and immigration tribunals, it is useful to explain briefly how the individual refugee applies to be reunited with their family. The refugee residing in the UK is known as the sponsor and it is they who make the application for reunion on behalf of their family members residing outside of the UK (a system also exists for in-country family reunion). The submission of the application is cost free, although through the removal of legal aid and the significant reductions to accessible legal aid and advisory services, legal support is often effectively denied to refugees. ${ }^{22}$ The process is considered by the government to be straightforward. Thus, following commencement of the Legal Aid Sentencing and Punishment of Offenders Act 2012, ${ }^{23}$ legal aid was removed (in England and Wales, it continues in Scotland) as the refugee applicants were considered able to complete the form and submit this along with supplementary evidence. The process has, however, been referred to as complicated, ${ }^{24}$ the application form is subject to change without notification, and therefore the refugee often will require assistance (by a person who understands the system) to complete the form correctly. This last point is particularly important. Collating the required documentation, understanding the nuances and variances of the language used within the application process, and to give the applicant and their sponsor "a voice" through their supporting statement, requires some form of assistance, navigation and support. On completion of the application, it is assessed and verified by a member of the UK civil service. This individual is called an Entry Clearance Officer (ECO) and it is their job to assess and determine whether the application for refugee family reunion should be approved or refused. Where refused, the decision is reviewed by an Entry Clearance Manager (ECM) and, where unsuccessful, the ECO or Visa Application Centre staff will issue the "reasons for refusal" letter to the refugee's applicant family members. Significantly, the process can be opaque ${ }^{25}$ and it is not uncommon for little feedback to be provided to the applicant where they have been unsuccessful in the applica-

\footnotetext{
${ }^{22}$ Refugee Action, an organisation which aids refugees and advocates on their behalf, published a report "Tipping the Scales: Access to Justice in the Asylum System" (2018) in which it found that 76\% of the 92 organisations surveyed were finding it 'very difficult' or 'quite difficult' to refer people on to legal representatives; since 2005 the proportion of not-for-profit legal and non-legal service providers had fallen by $64 \%$, and $56 \%$ of legal aid providers had been lost in the sector. See

https://www.refugee-action.org.uk/wp-content/uploads/2018/07/Access-to-Justice-July-18-1.pdf (accessed 1 July 2019).

${ }^{23}$ The commencement of the Legal Aid Sentencing and Punishment of Offenders Act 2012 on 1 April 2013 removed the legal aid available for refugee family reunion claims in England and Wales.

${ }^{24}$ For discussions of the implications for refugee family reunion see Beswick (2015); and Staver (2008).

${ }^{25}$ For instance, there is relatively little information regarding published or consistent time scales for the application process and over complexity in the use of the online visa application system (the TLS (a teleperformance company) contact website) and ancillary online registration services.

${ }^{26}$ The use of DNA evidence is such an example. On the basis that the refugee cannot prove to the ECO's satisfaction that he is the father of the applicant, DNA evidence is required. However, detailed instruction as to when, where and how the test will take place, and who should pay the fee are not provided to the refugee. Without support from an experienced advisor it may be difficult for the refugee to know where to gather this evidence. See Beswick (2015); and Connell, et al. (2010), where the costs of acquiring DNA evidence, along with the costs of submitting appeals hearings in court (not to mention the emotional cost to family) are considered.
} 
tion. ${ }^{26}$ If an application is refused, the sponsor/applicant is not provided with an opportunity to submit further evidence to either strengthen their claim, or to refute the reason for the refusal at first instance. The refusal leads to re-applications, appeals and/or applications for Exceptional Case funding to support the further expense of appeals. This has a financial and time cost for the sponsor, a court case hearing the appeal is funded by the taxpayer and the applicant may continue to reside in danger until these processes are exhausted.

Given the paper is interested in the use of a TJ approach to negate the worst effects of the current system of refugee family reunion and to assess the contribution of the Refugees (Family Reunion) Bill in this battle, two examples of problems in the system are raised. The first is the UK's instance on applying refugee family reunion through the immigration, not asylum system. The second is the concept of the family and how the UK's narrow approach adversely and unfairly affects refugees.

\subsection{Immigration or Asylum?}

The system of asylum in the UK is complex and heavily controlled by the State. The UK requires evidence to be presented which supports their claim and this is often difficult to establish and can lead to a large number of failed applications. Indeed, as of June 2019, the latest figures from the UK show that only $44 \%$ of initial decisions resulted in a grant of asylum or some other form of protection. This is exacerbated by the decision-making of the Home Office where many arbitrary decisions are made due to its consideration of the evidence available to be presented by the asylum seeker. This in turn leads to a legal challenge and the problems encountered there in terms of available advice and representation, the quality of that advice and representation and the emotional effects imposed on the individual forced to traverse this route to gain status. The Refugee Council of the UK also note that this system is even worse for female applicants who have difficulties, especially around the violence they have experienced which forms part of their application for asylum. ${ }^{27}$

A symptom of the refugee crisis, with individuals entering the UK having been separated from their families, is the necessity for interaction with, and the ability to successfully traverse, national and international ${ }^{28}$ rules and guidance to facilitate the reunion. A legal right to refugee family reunion derives from the 1951 Refugee Convention ${ }^{29}$ and is provided to recognised refugees who have been granted refugee status or, since October 2006, five-years' limited leave to remain under the Humanitarian Protection scheme. The right to family reunion is written into Part 8 and the FM section (Family Dependents) of the Immigration Rules. Significantly, refugee family reunion is a matter contained in the

${ }^{27}$ https://www.refugeecouncil.org.uk/information/refugee-asylum-facts/the-truth-about-asylum/ (accessed 25 August 2019).

${ }^{28}$ Such as the UNHCR, the United Nations Convention on the Rights of the Child and the Geneva Convention which, to further add to already existing complexity, do not dovetail neatly.

${ }^{29}$ See $R$ (Gudanaviciene and Others) v Director of Legal Aid Casework; the Lord Chancellor [2014] EWHC 1840 (Admin). 
immigration rules rather than as an asylum issue where it would seem a more natural fit. ${ }^{30}$ Currently, refugee family reunion finds itself between "regular" permitted immigration, a system of managed migration, and asylum, where individuals are forced to flee and often enter the UK clandestinely (including, perhaps, being trafficked or smuggled into the country) and face the vagaries of the complex, dynamic, underfunded and often degrading asylum system. The individual granted with status is also, since 2005 , generally to be issued with permission to reside in the UK for a period of five years. Their member of family who join them in the UK through the refugee family reunion system are issued with the same (remaining) period of time of residence. Hence an individual granted five years' right to reside in the UK and who is reunited with their family after one year has only four years' guaranteed right of residence. This period of time is applied to their family members too. Such a system impacts negatively on future decision-making about education, work and the rest of their lives.

\section{2. "Family", What Is a Family?}

Refugees in the UK are being left desperate and, in some instances, suicidal as a result of the immigration laws which prevent their reunification with their close family members. The Home Office's policies, along with the Immigration Act produce an uncertain and opaque application system, which, whilst allowing 'family' to include pre-existing nuclear family members, restricts children over the age of 18 to be joined with the refugee sponsor (unless an application 'outside of the rules ${ }^{31}$ is made). A report by the Refugee Council and Oxfam also identified that three-quarters of refugees in the UK have separated family members who are ineligible for refugee family reunion due to the Immigration Rules. ${ }^{32}$ In previous papers, we have identified the practical consequences for refugees with the application process and the problems encountered with post-arrival integration. ${ }^{33}$

There is no definition of the "family in international law and indeed, one of the reasons offered for discretion in this area is that a state party does not have exclusive jurisdiction in defining a family, because the definition has to be 'without discrimination'” (van Bueren, 1995: pp. 734-735). However, when one

\footnotetext{
${ }^{30}$ This is, however, a politically contentious perspective as there are positive and negative implications to such a proposition. For instance, if it only sat in asylum there is an argument that the family members should also be tested under the Geneva Convention principles and could be detained etc.

${ }^{31}$ For instance, applications may be made on the basis of need relating to the family member's age, Illness or a disability which requires personal care that may only be provided by the refugee relative in the UK.

${ }^{32}$ Refugee Council and Oxfam (2018)

https://policy-practice.oxfam.org.uk/publications/safe-but-not-settled-the-impact-of-family-separation-on -refugees-in-the-uk-620409 (accessed 1 July 2019).

${ }^{33}$ Marson \& Ferris (2018). The authors discuss the issues surrounding refugees and their families' integration into their new 'UK' life. Interestingly, the interpretation presented in the paper differs significantly on what post-arrival support and integration means compared with that of the Home Secretary Sajid Javid's idea that integration means replacing the existing 'Life in the UK' test for new citizens with a 'British Values' test and a strengthened English language requirement (speech delivered to the Conservative Party Conference, 2 October 2018). Available:

https://blogs.spectator.co.uk/2018/10/full-text-sajid-javids-conservative-conference-speech/ (accessed 1 July 2019).
} 
is offered, such as the definition provided in the Immigration Rules, in the UK context this is needlessly restrictive. The Rules permit an adult refugee in the UK to apply to be reunited with their spouse/partner and dependent children under the age of 18. These are the refugee's "family." A problem exists, which is certainly not an uncommon scenario, where the refugee's wife and minor children are eligible to be reunited with the sponsor in the UK, yet children over the age of 18 are not. A choice is then made as to whether the rest of the family reunite in the UK leaving the elder child(ren) in the home country or, as frequently happens, the family are separated (or the older child attempts to make their own way into the UK with the consequent risks involved). Of course a mechanism exists within Appendix FM of the Immigration Rules for family members, including a child, over the age of 18 , of the refugee to be reunited in the UK but this route is more onerous than the standard refugee family reunion and it is subject to an application fee. ${ }^{34}$ These "exceptional circumstances" cases are decided on a case by case basis, and hence are atypical and do not, even with the benefit of judicial intervention, affect the source legislation of family reunion. It is also worth noting that the numbers of visas granted outside of the Rules has decreased in recent years. ${ }^{35}$

Further, the current rules prevent child refugees to "sponsor" parents, grandparents and siblings to join them in the UK. In 2016, Lord Bates, on behalf of the government, commented that it would be inappropriate for children to sponsor their parents to join them in the UK as it "could result in children being encouraged, or even forced, to leave existing family units in their country and risk hazardous journeys to the UK in order to act as sponsors." ${ }^{36}$ Such scapegoating of individuals or groups in this way is exactly why TJ, as a philosophy, could achieve so much in the realm of refugee family reunion. As remarked by Diesen "... the justice system is too concerned with ... confirming the validity of statutory provisions instead of trying to resolve the pertinent problems arising in connection with the matter at issue." ${ }^{37}$

It was, however, in November 2017 where the government rejected calls presented in a report by MPs on the Home Affairs Select Committee for lone child refugees to be permitted to be reunited with their parents. The Committee had called for the mirroring of rights provided to adults for children to be able to live safely with their family via family reunionification, and that to deny these to

\footnotetext{
${ }^{34}$ In $M M$ (Lebanon) \& Ors [2017] UKSC 10 the Supreme Court assessed whether the "minimum income requirement" of partners and children of the sponsor applying for entry clearance to the UK was lawful. The requirement of the sponsor having an annual income of at least $£ 18,600$, with an additional $£ 3,800$ for the first child and $£ 2,400$ for each additional child had, in some instance, a disproportionately negative effect. Sponsors from certain ethnic groups (para. 81) tended to earn less, and regional variations in income were common (although ultimately it found the principle of minimum income to be lawful - para. 87). However, at paras. 92 and 109, the Court found the requirement's negative impact on the duty to promote the welfare of children to be "wrong in law" and thereby unlawful.

${ }^{35}$ In 2001, 77 visas were granted outside of the rules, in 2014, this figure had fallen to 12 (see House of Lords Written Question 3957, 2 December 2015).

${ }^{36}$ Communication, Lord Bates to Lord Rosser, 8 January 2016, quoted at: https://helprefugees.org/news/child-refugees-sponsor-families/ (accessed 1 July 2019).

${ }^{37}$ Diesen (2007) p. 156. Available: http://www.scandinavianlaw.se/pdf/51-6.pdf (accessed 1 July 2019).
} 
children was "perverse." It is worth noting at this point that the UK is one of very few countries who deny family reunion to unaccompanied child refugees. The UNCRC ${ }^{38}$ provides, subject to limited exceptions, that "States Parties shall ensure that a child shall not be separated from his or her parents against their will" ${ }^{39}$ and further that these applications will be dealt with by the State "in a positive, humane and expeditious manner." ${ }^{40}$ This obligation relates not to the expeditious administration of applications but speaks more to State's not breaching the provision by forcibly separating a child from their parents. The UNCRC has not been implemented directly into national law and the enforcement of an international convention is problematic at best. ${ }^{41}$ Without the government will to take up these rights and transpose them into national law, they present a standard to be achieved without the powers to compel any action at legislative or judicial levels. Certainly at present, extrinsic sources of international law may not be used to displace the object and purpose of legislation, whilst they can and have been used to limit the State's obligations under, for example, the 1951 United Nations Convention Relating to the Status of Refugees. Whether Convention rights can act as an appropriate interpretive aid to inform future legislative initiatives such as the Refugees (Family Reunion) Bill remains to be seen. However, given the current political climate and the lack of positive instruction in this area, international treaties have often been used to reduce rather than strengthen the protection afforded to groups including refugees. To this point, the system of refugee family reunion may be better served through a strict textual interpretation rather than relying on a teleological or purposive method.

The refugee family reunion rules also apply to refugees living in the UK and do not allow a person identified as a refugee but residing abroad to be reunited with family members in the UK, if those family members in the UK either are not refugees or lack humanitarian protection status. Hence, a British citizen, married to an Eritrean national who has been recognised by the UNHCR as a refugee, living in Turkey would not be able to bring their spouse to the UK through the refugee family reunion rules. The course available to them is via the spousal visa route and this is subject to the (restrictive and often, in relation to refugees, unobtainable) applicable income thresholds. ${ }^{42}$

Examples do exist of the judiciary providing a favourable ruling in relation to the Immigration Rules, but this does not defeat the underlying problems of the legislation and is frequently an exception rather than the rule. For instance, in $H A \&$ Ors, $R$ (on the application of) $v$ Secretary of State for the Home Depart-

${ }^{38}$ The United Nations General Assembly Res. 44/25, 20 Nov. 1989; entered into force 20 Sept. 1990. Art. 10, UNCRC.

${ }^{39}$ Article 9(1).

${ }^{40}$ Article 10(1)

${ }^{41}$ The UNCRC contains no powers to penalise countries that breach its provisions. It cannot compel action on the part of the signatory State, even through the optional individual complaints mechanism.

${ }^{42}$ See the Refugee Council briefing on Refugee Family Union, Immigration Bill, Committee Stage in the House of Lords, February 2015.

${ }^{43} \mathrm{HA} \&$ \& Ors, $R$ (on the application of) $v$ Secretary of State for the Home Department (Dublin III; Articles 9 and 17.2) [2018] UKUT 297 (IAC). 
$m e n t^{43}$ a stateless Bidoon from Kuwait was granted humanitarian protection and became a British citizen in 2013. He then applied to be joined by his wife and child but, as now a British citizen and not a refugee, was no longer subject to the "preferable" rules but rather the normal immigration rules with the application of the minimum earnings threshold. A refusal was issued but the wife and child managed to escape to Greece where, under the Dublin III Regulation, the Greek authorities suggested to the UK that the wife and child should move there given the existing family member (under the "family unity" provision). The UK refused arguing that as the husband was no longer a refugee Dublin III did not apply. The crux of the case came to the interpretation of the law. Did the law apply restrictively to individuals currently benefiting from international protection or was it extended to more encompassing current and former beneficiary (Art. $17(2))$ ? Unusually in this case, the tribunal determined the case on the latter and the family were reunited.

Importantly, from the headline of the judgment it appears that a wide discretion of action is available to the Secretary of State and despite the potential for inconsistency in the Immigration Rules and Art. 9 and Art. 17(2) Dublin III, no action is required from the State to change those Rules or their interpretation:

3) The decision impugned in this case was one arising from the exercise of a discretion conferred on the respondent. On that basis, and following Padfield $v$ Ministry of Agriculture, Fisheries and Food, ${ }^{44}$ a court should not compel any authority to do more than consider the exercise of a power which is merely permissive and does not impose an obligation to act.

\section{4. "The Adoption of a Therapuetic Jurisprudence Philosophy"?}

To begin it is important that we establish what we understand by the term TJ. TJ is a complex philosophical approach ${ }^{45}$ which has been established as intentionally broad, lacking a restrictive definition, so as to incorporate different dimensions and not to be overly prescriptive or restrictive. ${ }^{46}$ Its comprehensibility leads to a level of uncertainty, but it is in this uninhibitedness where it may be applied most constructively. Such flexibility enables it to be applied and incorporated into a range of legal and non-legal fields. However, it is possible to identify TJ as a form of legal philosophy which attempts to discuss and highlight areas of importance which are often overlooked in traditional legal processes. In this regard, the law is looked at in relation to its human, emotional and psychological sides which, as many areas of law will impact, can have both therapeutic and anti-therapeutic effects (Winick \& Wexler, 2003; Wexler, 2011a: p. 34). Therefore, as a philosophy, TJ aims to develop approaches

${ }^{44}$ Padfield v Ministry of Agriculture, Fisheries and Food [1968] AC 997.

${ }^{45}$ Complex in the sense that it holds both a law reform agenda, whilst also aiming to assign therapeutic goals to current legal systems within the limits of due process and justice. See Patry (1998). Available: https://scholarlycommons.law.cwsl.edu/cwlr/vol34/iss2/12 (accessed 1 July 2019).

${ }^{46} \mathrm{As}$ it remains a developing comprehensive law approach. 
which maximise the positive psychological and emotional effects of the law and, using the behavioural sciences as an underpinning, seeks to develop therapeutic outcomes for all stakeholders (See Wexler, 2013). It enables the law to act as a "therapeutic agent" (Winick, 1996) by requiring members of the legal profession to incorporate theory and empiricism to inform and thereby improve the administration of justice. Importantly at this stage is to recognise that $\mathrm{TJ}$ does not exist purely as a theoretical approach but instead has moved from theory to practice (Wexler, 2011a) and, internationally, has been endorsed within rulings which conduct the administration of legal enterprises (Hora, Schma, \& Rosenthal, 1999; Perlin, 2018).

TJ has a very well developed history and strong practical application (Wexler, 2014b) in areas where individuals within the legal system face a strong emotional component. For example, mental health law and drug courts (Hora, 2002; Hora, Schma, \& Rosenthal, 1999; KPMG, 2014; Wexler \& Winick, 1996) have for many years been subject to scrutiny and the application of TJ principles to assist all members of the legal system to better understand the emotional needs and psychological effects of the law in practice. ${ }^{47}$ Adopting such a philosophy has encouraged the participants to react creatively and to reimagine how behavioural science literature can infuse therapeutic law into these interactions (Wexler, 1999). The drug courts in the US have empowered the courts to determine treatment plans, establish rules by which the defendant must comply, explain the decision-making process, work collaboratively with all members of the court to determine mutually beneficial approaches and the results (among others) have been more engaged defendants at review hearings and a reduced recidivism rate.

As has already been identified, $\mathrm{TJ}$ is concerned with how judiciaries apply procedures and the law which respect the interests of the individual and maintain their dignity (Winick \& Wexler, 2003). How this is achieved, and due to the breadth of TJ as a discipline, has resulted in some interactional principles being identified. These include acceptance, empathy, empowerment, hope and expectancy, a future focus, self-expression, warmth and respect (Winick \& Wexler, 2003; Petrucci, 2002). Some of these features have also been identified in Goldberg's (2011) judicial training manual, which identifies key techniques as: empathy, respect, active listening, a positive focus, non-coercion, non-paternalism, and clarity. Importantly, research by Tyler \& Bies (1990) concluded that the decisions reached by judges were considered insignificant when compared with perceived levels of fair treatment during the case. The legitimacy of explanations, the identification and explanation of procedural rules and outcomes led to TJ compliant results. However, this does often rely on the judge acting in a way which can facilitate a therapeutic outcome. What Perlin (2012) refers to as the charisma of the judge is particularly important in the running of a case and its outcome, and this refer specifically to the 'wine' component of therapeutic jurisprudence. The misapplication of procedural rules, and its anti-TJ effects, was re-

${ }^{47}$ Referred to in some texts as "emotional lawyering" with a deliberate moving away from the traditional lawyerly adversarial approach to conflict;_Douglas (2015); and Silver (1999). 
cently demonstrated by the Home Secretary in $R$ (Help Refugees) $v$ Secretary of State for the Home Department ${ }^{48}$ and $R$ (Citizens UK) $v$ Secretary of State for the Home Department. ${ }^{49}$ Here the government's implementation of Immigration Act 2016 s. 67 (referred to as the "Dubs amendment") ${ }^{50}$ was found to be in breach of the common law duty of procedural fairness by failing to provide adequate reasons to affected unaccompanied asylum seeking children who were rejected for transfer to the UK through s. 67.

TJ as a philosophy was established by Bruce Winick and David Wexler. Wexler famously established a metaphor to help explain how TJ, as an examination tool for the potential or efficiency of a legal setting, could be utilised. The bottle and the wine are both essential characteristics of the legal setting (Wexler, 2014 b) with the bottle referring to the legal structure, procedure and mechanisms under which the law would operate. The wine aspect of the analogy refers to the actual application of these rules within the settings as established (Lens, Katz, \& Suarez, 2016). It also considers the application of the law on a micro level, such as the style used by the judge (Goldberg, 2011). The wine analogy is most discussed in the literature due to its more malleable essence and that it may be applied easier than can the bottle be changed. What is required to ensure a TJ rich environment is established are highly trained, skilled and knowledgeable members of the legal system, and a willingness for advisers, advocates and judges to be receptive to applying the TJ friendly wine (Wexler, 2013).

The bottle, often referred to as the legal landscape, was structured around laws, provisions, rules, procedures and the rule of law that govern the legal setting. By its very nature, this bottle was difficult to change (Wexler, 2014b), develop or to be manipulated. It is relatively easy to see how such a metaphor could be used successfully in areas such as criminal proceedings and especially drug courts (Wexler, 2014a). These are where the TJ principles were initially founded. It is also appropriate to view the bottle in relation to the current laws regarding refugees and family reunion issues. There are strict rules and procedures by which all the actors in the legal system are obliged to follow and these are difficult to change, even by a well-meaning and emotionally attentive judge.

The bottle and the wine are essential elements for the most enriching application of TJ. Where this is not possible due to, for example, an unfriendly bottle, it remains possible for TJ friendly wine to still be "poured." This will undoubtedly undermine elements of its effectiveness, but skilled practitioners with the correct TJ "know-how" may still be placed and have an opportunity to ensure a positive therapeutic impact from the setting. An unfriendly bottle may be established through elements such as the constraints of legislation, the rule of law, and procedural norms which impose behaviours on the legal actors. In many instances this is how the current system of refugee family reunion operates, although of

$48 R$ (Help Refugees) v Secretary of State for the Home Department [2018] EWCA Civ 2098.

${ }^{49} R$ (Citizens UK) $v$ Secretary of State for the Home Department [2018] EWCA Civ 1812. Further, in this case the Home Secretary was found to have misled the court in giving evidence.

${ }^{50}$ The scheme, named after Lord Dubs who introduced it, whereby unaccompanied children in the refugee camp in Calais would be able to live in the UK despite having no family link. 
course legislative changes are on the horizon and judges skilled in $\mathrm{TJ}$ techniques can at least mitigate against the worst effects of the "current" bottle.

The power of $\mathrm{TJ}$ is that it does not seek to automatically displace other perspectives and values of the law or within a legal setting (Perlin, 2013). Indeed, as Winick and Wexler identify, "other values such as justice and due process can be fully respected" within its application (Wexler \& Winick, 1996). Whilst it holds a modified law reform agenda and is committed to promoting the therapeutic legal reform of systems, such reform must sit within the practical limits of due process and justice, and it consequently draws attention to the subtler consequences of legal processes (Perlin, 2013; Wexler \& Winick, 1996; Gal \& Wexler, 2015). The use of TJ does not also mean that norms will not at times clash. The individual refugee wants to be joined in their new life with their family, yet the immigration system, including refugee family reunion, is concerned at a public level with immigration rates and its control. The legal system may be the place where, when used therapeutically, the causes and possible solutions to such normative disputes may be discovered and resolved.

The refugee family reunion system in the UK (as a "bottle"), whilst not fulfilling the caricature of an adversarial system completely, cannot be said to have altered the existing legal order and adopted the lens of $\mathrm{TJ}$ through a rejection of adversarialism. The Refugees (Family Reunion) Bill, however, whilst not changing the fundamental application (or the "wine" element of Wexler's analogy) does address and build upon some of the positive structural components inherent in the system. This, primarily, surrounds changes to the current practice of facilitating children to be reunited with their families and the concept of the family to be broadened to include older children and the applicant's ascendants. Both of these groups are currently excluded, in the strict application and interpretation possible of the current law, from the refugee family reunion system.

International conflicts and the circumstances that can lead to an individual becoming a refugee, the immigration system and the concerns surrounding the processing of these individuals, and the refugees' applications for family reunion each lend themselves to a need to address the resultant "psycho-legal soft spots" ${ }^{\prime 1}$ present. TJ has expanded preventive law ideas. Where preventive law is concerned with anticipating legal soft spots, $\mathrm{TJ}$ is concerned with anticipating psycho-legal soft spots. This is in terms of "the psychological baggage that often accompanies legal moves and measures" (Wexler, 2011b: p. 34) or those areas where "...legal intervention or procedures ... may lead to anxiety, distress, depression, hard and hurt feelings, etc." ${ }^{2}$ This means considering the psychological/emotional risk that legal actions might pose and which has led to ideas around legal counselling being developed (Patry, 1998). The nature of the refugee's experience of reaching the UK, their continued separation from their fam-

\footnotetext{
${ }^{51}$ Which may lead to "strongly negative emotional reactions that diminish the client's psychological wellbeing.” Winick (2000), at p. 108.

${ }^{52}$ Patry (1998). Available: https://scholarlycommons.law.cwsl.edu/cwlr/vol34/iss2/12

(accessed 1 July 2019).
} 
ily, along with an application process of uncertain length and outcome, can produce the very negative emotional reactions or psycho-legal soft spots which can cause problems in the relationship between the refugee and the legal system and its actors. This, as evidenced by Wexler and Winick (2006), can produce a psychological resistance and other defence mechanisms that prevent the refugee from effectively articulating their story, their needs and their interests. These are crucial in refugee family reunion applications.

Having identified the underlying principles of TJ and Wexler's "wine and bottle" metaphor, we now continue through the use of several examples to demonstrate how the legal and administrative system in the UK produces anti-therapeutic effects. This is the inflexible "bottle" element of the metaphor discussed in section 5. In section 6, we continue by explaining how a TJ approach can be the therapeutic "wine" which mitigates against the worst effects of the law.

\section{A Broken Bottle? The Anti-Therapeutic Effects of the Law}

There are, perhaps, too many examples of problems inherent in the immigration and asylum system as they apply to refugees to be explored in one article. To illustrate just two contemporary issues, the following are used. The first is a problem experienced by detainees in the asylum system, and the second with the concerns over the removal of legal aid and the restrictive interpretation of the "family."

The Immigration Act 2016 also established changes to the system of immigration bail (with a commencement date of January 2018). The 2016 Act repealed the Immigration and Asylum Act 1999 s. 4(1)(c) which enabled homeless migrants to apply for government accommodation from within a detention centre where they had no other residence established upon release. The charity Bail for Immigration Detainees found, through a Freedom of Information request, the negative effects that this scheme had caused. In the first five months of 2018 in only 24 cases was accommodation offered compared with 2800 offers of accommodation in the previous year. The charity also identifies a series of scenarios which, whilst purporting to provide other forms of assistance and redress to homeless migrants seeking accommodation, actually merely compound an already broken system. For instance, migrants who are not asylum seekers can request accommodation through the Immigration Act 2016, para. 9, Sch 10. However, this part of the Act has no mechanism for such an application to be made. Failed asylum seekers may apply for accommodation through the Immigration and Asylum Act 1999, s. 4(2) where they have proof that they are due to be released within 14 days of the application. Detainees are not provided with a date for their release. Finally, other asylum seekers may apply for accommodation through the Immigration and Asylum Act 1999, s. 95 where they are "destitute." Detainees, according to the Home Office, are by their nature not destitute and thus the asylum seeker is ostensibly forced to leave detention, live on the street where they will be destitute before being able to satisfy the requirements of s. 95 
and apply for accommodation. Also, judges at the First-Tier Tribunal will be unlikely to release a person who does not have accommodation arranged. Consequently such individuals remain in detention due to their lack of accommodation. A most unfair and vicious circle in which to be caught.

The significance of the removal of legal aid in England and Wales to refugees seeking reunion with their family members cannot be underestimated. This has led to a reduction in the law firms offering refugee family reunion services (through firms closing and practitioners leaving the profession), ${ }^{53}$ and those who do provide such an unregulated service may charge fees which make accessing the service impractical. Refugees who wish to appeal against a refusal to award legal aid may complete an Exceptional Case Funding application, but these are very complex forms and often require the legal assistance denied to the refugee in the first instance.

Given the problems encountered in the aftermath of the introduction of the Legal Aid, Sentencing and Punishment of Offenders Act 2012 Angus MacNeil MP, supported by a number of refugee rights' groups including Amnesty International and the UNHCR, introduced a private members' Bill titled the "Refugees (Family Reunion) Bill." The Bill addresses two issues which currently place England and Wales out of step with not only other European countries but, in the case of legal aid, with Scotland too. Taking the legal aid issue first, the Bill intends for the reintroduction of legal aid to help refugees with the navigation through the complicated application process.

Secondly, unlike most other countries and their dealings with refugee family reunion applications, in the UK adult applicants are entitled to apply to be reunited with their spouse and descendants (under the age of 18). To successfully apply for adult children, parents and grandparents requires a different claim on the basis of exceptional medical or humanitarian grounds. Success on applications by children for reunification with their family (here a mother and the applicant's brother) had been achieved via the application of Article 8 of the ECHR in $A T$ and another. ${ }^{54}$ The Upper Tribunal held that statutory instructions ${ }^{55}$ to the UK Border Agency on making arrangements to safeguard and promote the welfare of children, issued under the Borders, Citizenship and Immigration Act 2009 s. 55 were paramount. Indeed, Judge McCloskey remarked that the provisions of the European Court of Human Rights, the International Covenant on Civil and Political Rights, the EU Reception Conditions Directive ${ }^{56}$ and UNCRC had to be fulfilled when the UK Border Agency exercises its functions. Conse-

\footnotetext{
${ }^{53}$ Legal Action "Review of Evidence to LASPO Act Impact Inquiry" (2014) June, p. 9.

${ }^{54} A T$ and another [2016] UKUT 227 (IAC).

${ }^{55}$ Home Office/Department for Children and Families, "Every Child Matters", November 2009.

${ }^{56}$ Council Directive 2003/9/EC of 27 January 2003 laying down minimum standards for the reception of asylum seekers (replaced by Directive 2013/33/EU). The new Directive, agreed on 14 June 2018 further adds protection for refugee family reunion: "The definition of family members... will include dependent adult children and families formed before arrival in the EU, and not just those coming from the country of origin... As regards to siblings, member states may choose to include them in the definition." Available: http://www.europarl.europa.eu/news/en/press-room/20180614IPR05803/reception-conditions-for-asylum -seekers-agreed-between-meps-and-council (accessed 1 July 2019).
} 
quently, the Secretary of State and the bodies which act with the authority of the government, including UK Border Agency, UK Visas and Immigration and the ECO and ECMs were required to give effect to international treaties when making decisions affecting children. Of course, whilst successful appeals in the Upper Tribunal and instructions for the judiciary to utilise statutory interpretation to give indirect effect to the international provisions are to be welcomed, they do not create new statutory rights. An individual case may find incompatibilities with ECHR rights rather than the relevant general rules or policies. Thus continues the debate between literal and purposive methods of interpretation, its narrow or broad application, (Sneath, 1985) not to mention the uncertainty this maintains (Walshaw, 2014).

The Bill would expand the definition of who qualifies as a family member and thus allow child refugees to sponsor their close family members (such as their parents) to join them in their new life in the UK. This is important for the child refugee when beginning to rebuild their life in a new country, with the myriad issues which such upheaval brings. It also aims to help further protect such vulnerable people. "At the moment, the UK Government's regressive and strict immigration laws have punished child refugees by cutting them off from their families, which leaves them vulnerable and risks young people being exploited or possibly trafficked without that family support around them.."57

\section{Restorative Wine: Infusing a Therapeutic Paradigm in Decision-Making}

This paper is most concerned with the development of legislative initiative to remedy the problems encountered by refugees in the UK attempting to be reunited with their families. There is also a need, either in the absence of legislation or administrative instruction, or in conjunction with these moves to consider the wine dimension of the law and how this can elevate new laws through their application or ameliorate the worst effects of the current systems. First, a willingness is required of legislators to consider the therapeutic wellbeing of those exposed to the law. Be this to motivate rehabilitation and instil mechanisms that help build strengths around pro-social behaviours in criminal law, or those that encourage and facilitate reintegration and settled status in relation to refugee family reunion. Legislation and the way the laws are interpreted has a profound effect on the people involved and none more so than the refugees seeking to be reunited with their families. It is widely accepted that refugees have typically sustained levels of psychological distress on their journey to the UK, and this continues following their arrival in safety (Stolle \& Wexler, 1997; Stolle, Wexler, \& Winick (Eds.), 2000). Male refugees are known to suffer survivor guilt ${ }^{58}$ having left their families behind in an unsafe situation, they are frequently

${ }^{57}$ Settle (2018) The Sunday Herald

http://www.heraldscotland.com/news/16090953.SNP MP makes parliamentary bid to end quot griev ous injustice quot for Syrian refugees/ quoting Angus MacNeil (accessed 1 July 2019).

${ }^{58}$ Specifically, in relation to adolescents see Herman (1992); and Stotz, Elbert, Müeller, \& Schauer (2015). 
distressed at the administrative and sometimes legal processes ahead of them to be reunited, and their sense of helplessness and confusion as to the Byzantine asylum system facing them is palpable. Thus, the non-legal aspects or consequences (Patry, 1998) that the law may have and the broader context of the individual's interaction with legal processes (Wexler, 2005; 2008; 2011b) may aid in a movement away from the typical adversarial paradigm/culture of conflict that has historically dominated the legal landscape in the UK (Karlberg, 2004).

Increasingly, a movement has been gathering pace for legal scholars and practitioners to stop seeing the law as a means of categorising and resolving legal problems but to consider its effects (Cruz, 2009). This is where the psycho-legal consequences of the law may prevail. For example, family law and immigration law, supporting as they do children and refugees and whose work may therefore evoke strong emotional reactions (such as refugee family reunion) seem especially apt. Thus, the concept of emotion in the legal system is not something to be avoided (Maroney, 2006), rather the traditional paradigm of training lawyers $^{59}$ to detach themselves emotionally from their clients negates the relationship between the two (Gerdy, 2008: p. 18).

The current and proposed system of refugee family reunion often fails to use international sources of law and instructive comments to inform decision-making. The application process, as already noted, is based on a generic series of questions which are often not relevant in the sponsor's circumstances and establishes obfuscation rather than clarity. As way of an example, refugee family reunion does not require satisfaction of the "adequate maintenance and accommodation" test for persons seeking to reside in the UK. But, as there is no bespoke form or indeed system for refugee family reunion, sponsors are forced to comply with completing the appendix forms which asks for this information. It is possible that this aspect of the form is not tested and if it were it would likely be subject to a judicial review. However, at the time of writing this has not occurred. It is worth reiterating at this stage that the submission of the application form by the sponsor is considered by an ECO and a negative decision is then confirmed by an ECM before the sponsor's family are informed. This is performed through a paper-based exercise with no ability or availability for the sponsor to speak directly with the ECO, to answer questions, or to provide supplementary and supporting evidence before a decision is made. The letter sent to the sponsor's family is reminiscent of a template document and uses accusatory language relating to the credibility of the evidence and can even extend to that of the existence of any relationship between the sponsor and their family. This power imbalance, the lack of transparency, and the efficacy of attempting to address the defects of the first application (where such indication is communicated) all establish a result of a process which is anti-therapeutic. A negative result regarding a sponsor's application for family reunion will always be disappointing, but here the process itself compounds the negativity and causes despair

${ }^{59}$ Historically, this was seen on an international basis, see Menkel-Meadow (1994). But, it is becoming more prominent in UK lawyer training: see Dagilyte and Coe (2014). 
in the sponsor as to how they may put right the reasons for the refusal.

When a sponsor proceeds to appeal a negative decision in the courts, they likely find that the court is (perhaps naturally) more concerned with the resolution of the conflict between the sponsor's application and the Home Office, rather than considering the reasoning behind the case arriving in the court. There are many elements of the application process which are notoriously problematic and known by practitioners, but not necessarily addressed by the courts. First is the complexity of the application form with the duplication of information required, particularly for individuals who may not be able to confidently communicate in English (Beswick, 2015). There is a requirement for irrelevant details of matters, such as the sponsor's housing and their future needs when (if eventually successful) their family joins them. ${ }^{60}$ The details of the reasons for a refusal often will not specifically address defects in the application which are readily addressable by the sponsor. And, concerns continue to be raised relating to the need for documentary evidence to be submitted to establish the on-going relationship between the sponsor and their family (which may no longer exist, Gower \& McGuiness, 2016). It is in the failure to address these systemic and underlying problems, and an unwillingness or inability to consider long-term solutions to these, that perpetuates the difficulties. The treatment of the sponsor when exposed to legal and non-legal issues, and the psycho-legal effects which arise therefrom, are important factors in the experience of the sponsor. Further, as Diesen identifies, "This does not mean, however, that adjudication influenced by $\mathrm{TJ}$ ideals implies that the judge shall act as a welfare officer, and that the court shall abandon its traditional adjudicative functions, offering instead panoply of rehabilitative services and social measures."61 Rather, TJ supplements the existing structures by exploring underlying factors that can positively raise issues which requires a judicial, and even legislative, response. It encourages discussion, collaborative working and respect which all direct the parties to reaching a settlement which complies with the law, and uses the law to help parties rather than being limited to simply adjudication or the administration of rules.

\section{Conclusion}

In this paper, we have attempted to provide an amalgamation of the bodies of literature and principles surrounding TJ, and to demonstrate their use in the application to forthcoming (and existing) legislative provisions regarding refugees. The values underpinning the comprehensive law movement are applicable to all involved in the administration of refugee family reunion law. To reiterate the points as presented in this paper, and which are demonstrated through the experience of practitioners and clients alike, existing laws, underpinned by humanitarian ideals, are frequently hampered by a system which is inflexible, often

\footnotetext{
${ }^{60}$ See the comment made earlier in the paper regarding family reunion which does not require satisfaction of the "adequate maintenance and accommodation" test but which is still contained in the appendix forms.

${ }^{61}$ Diesen (2007). Available: http://www.scandinavianlaw.se/pdf/51-6.pdf (accessed 1 July 2019).
} 
opaque, and does not allow for the nuances of an emerging and developing refugee crisis. Increasingly, unaccompanied children are finding their way to the UK as refugees and are unable, through the Immigration Rules on refugee family reunion, to sponsor applications from family members (such as their parents and siblings). The removal of legal aid for refugee family reunion cases has had a particularly negative effect on applicants. Decisions on such family reunion cases can take several months to be processed and a negative decision because of some procedural failing on behalf of the refugee's application can be devastating and cause great hardship to them and their family members trapped abroad. The practical effects may be eased through the enactment of the Refugees (Family Reunion) Bill which addresses some key problems (although, of course, many others still exist). Whether the Bill proceeds to an Act of Parliament is questionable, as is the future direction to be taken by the UK government following the conclusion of the Brexit negotiations. However, regardless of the laws or policy in place, what we hoped to have demonstrated in this paper is how those working in the refugee family reunion sector can, through adopting a TJ philosophy, mitigate against the worst of the anti-therapeutic effects of the current law and ensure that the TJ effects of the new Bill are maximised.

\section{Conflicts of Interest}

The authors declare no conflicts of interest regarding the publication of this paper.

\section{References}

Beswick, J. (2015). Not So Straightforward: The Need for Qualified Legal Support in Refugee Family Reunion. London: British Red Cross.

Boswell, C. (2002). Addressing the Causes of Migratory and Refugee Movements: The Role of the European Union. New Issues in Refugee Research, Working Paper No. 73, Switzerland: UNHCR Evaluation and Policy Analysis Unit.

Castles, S. (2011). Understanding Global Migration: A Social Transformation Perspective. Journal of Ethnic and Migration Studies, 36, 1565. https://doi.org/10.1080/1369183X.2010.489381

Connell, J., Mulvey, G., Brady, J., \& Christie, G. (2010). One Day We Will Be Reunited: Experiences of Refugee Family Reunion in the UK. Glasgow: Scottish Refugee Council.

Cruz, E. H. (2009). Through the Clinical Lens: A Pragmatic Look at Infusing Therapeutic Jurisprudence into Clinical Pedagogy. Thomas Jefferson Law Review, 30, 463-485.

Dagilyte, E., \& Coe, P. (2014). Professionalism in Higher Education: Important Not Only for Lawyers. The Law Teacher, 48, 36. https://doi.org/10.1080/03069400.2013.875303

Diesen, C. (2007). Therapeutic Jurisprudence-An Introduction from a Swedish Perspective. Scandinavian Studies in Law, 51, 131-162.

Donoghue, J. (2014). Transforming Criminal Justice? Problem-Solving and Court Specialisation. Routledge Frontiers of Criminal Justice, Abingdon-on-Thames: Routledge.

Douglas, S. (2015). Incorporating Emotional Intelligence in Legal Education: A Theoretical Perspective. E-Journal of Business Education and Scholarship Teaching, 9, 56-71.

Faist, T. (2000). The Volume and Dynamics of International Migration and Transna- 
tional Social Spaces. Oxford: Oxford University Press. https://doi.org/10.1093/acprof:oso/9780198293910.001.0001

Fortuny, K., Hernandez, D. J., \& Chaudry, A. (2010). Young Children of Immigrants: The Leading Edge of America's Future. Washington DC: Urban Institute.

https://doi.org/10.1037/e721852011-001

Gal, T., \& Wexler, D. B. (2015). Synergizing Therapeutic Jurisprudence and Positive Criminology. In N. Ronel, \& D. Segev (Eds.), Positive Criminology (pp. 85-97). New York: Routledge. https://doi.org/10.4324/9781315796536-6

Gerdy, K. B. (2008). Clients, Empathy, and Compassion: Introducing First-Year Students to the "Heart" of Lawyering. Nebraska Law Review, 87, 18.

Goldberg, S. (2011). Problem-Solving in Canada's Courtrooms: A Guide to Therapeutic Justice. Therapeutic Jurisprudence. Paper 3, Ottawa: National Judicial Institute. https://www.nji-inm.ca/index.cfm/publications/problem-solving-in-canada-s-courtroo ms-a-guide-to-therapeutic-justice-2nd-edition/?langSwitch=en

Goodman, R. D., Vesely, C. K., Letiecq, B., \& Cleaveland, C. L. (2017). Trauma and Resilience among Refugee and Undocumented Immigrant Women. Journal of Counselling and Development, 95, 309-321. https://doi.org/10.1002/jcad.12145

Goodwin-Gill, G. (2001). Editorial: Asylum 2001-A Convention and A Purpose. International Journal of Refugee Law, 13, 1-2. https://doi.org/10.1093/ijrl/13.1 and 2.1

Gower, M., \& McGuiness, T. (2016). The UK's Refugee Family Reunion Rules: Striking the Right Balance? Briefing Paper No. 07511, London: House of Commons Library. http://www.refworld.org/pdfid/58ac50564.pdf

Harris, C. (2018). There Is No Access to Justice If the Public Cannot Understand It. Thetimes.co.uk 20 September.

https://www.thetimes.co.uk/edition/law/there-is-no-access-to-justice-if-the-public-can not-understand-it-przdt50rn

Herman, J. L. (1992). Trauma and Recovery: The Aftermath of Violence-From Domestic Abuse to Political Terror. New York: Basic Books.

Home Office/Department for Children and Families (2009). Every Child Matters.

Hora, P. F. (2002). A Dozen Years of Drug Court Treatment Courts: Uncovering Our Theoretical Foundation and the Construction of a Mainstream. Paradigm Substance Use and Misuse, 37, 1469-1488. https://doi.org/10.1081/JA-120014419

Hora, P. F., Schma, W. G., \& Rosenthal, J. T. A. (1999). Therapeutic Jurisprudence and the Drug Treatment Court Movement: Revolutionizing the Criminal Justice System's Response to Drug Abuse and Crime in America. Notre Dame Law Review, 74, 439-537.

House of Lords and House of Commons Joint Committee on Human Rights (2004). The Nationality, Immigration and Asylum Act 2002 (Specification of Particularly Serious Crimes) Order 2004. Twenty-Second Report of Session 2003-04, HL Paper 190, HC 1212.

Inter-Governmental Consultation on Asylum, Refugee and Migration Policies in Europe, North America and Australia (1997). Report on Family Reunification: Overview of Policies and Practices in IGC Participating States.

Jastram, K., \& Newland, K. (2003). Family Unity and Refugee Protection. Cambridge: Cambridge University Press. https://www.refworld.org/docid/470a33be0.html

KPMG (2014). Evaluation of the Drug Court of Victoria. Final Report Magistrates' Court of Victoria. Government Advisory Services, Australia.

https://apo.org.au/sites/default/files/resource-files/2014/12/apo-nid54071-1194101.pdf

Legal Action (2014). Review of Evidence to LASPO Act Impact Inquiry (p. 9). 
Lens, V., Katz, C. C., \& Suarez, K. S. (2016). Case Workers in Family Court: A Therapeutic Jurisprudence Analysis. Children and Youth Services Review, 68, 107-114. https://doi.org/10.1016/j.childyouth.2016.06.027

Letiecq, B. L., Grzywacz, J. G., Gray, K. M., \& Eudave, Y. M. (2014). Depression among Mexican Men on the Frontier: The Role of Family Separation and Other Structural and Situational Stressors. Journal of Immigrant and Minority Health, 16, 1193-1200. https://doi.org/10.1007/s10903-013-9918-1

Maroney, T. A. (2006). Law and Emotion: A Proposed Taxonomy of an Emerging Field. Law and Human Behavior, 30, 119-142. https://doi.org/10.1007/s10979-006-9029-9

Marson, J., \& Ferris, K. (2018). After Arrival, the Problems Facing Refugees and Their Families: A Clinical Legal Response. International Journal of Clinical Legal Education, 25, 185-217. https://doi.org/10.19164/ijcle.v25i2.726

Menkel-Meadow, C. (1994). Narrowing the Gap by Narrowing the Field: What's Mission from the MacCrate Report-of Skills, Legal Science and Being a Human Being. Washington Law Review, 69, 593.

Office of the United Nations High Commissioner for Refugees (UNHCR) (2001). Summary Conclusions on Family Unity. Global Consultations on International Protection, Geneva Expert Roundtable 8-9 Nov. 2001.

Patry, M. W. (1998). Better Legal Counseling through Empirical Research: Identifying Psycholegal Soft Spots and Strategies. California Western Law Review, 34, 439-455.

Pereira, K. M., Crosnoe, R., Fortuny, K., Pedroza, J.-M., Ulvestad, K., Weiland, C., Yoshikawa, H., \& Chaudry, A. (2012). Barriers to Immigrants' Access to Health and Human Services Programs. Washington DC: Office of the Assistant Secretary for Planning and Evaluation.

Perlin, M. L. (1994). Therapeutic Jurisprudence: Understanding the Sanist and Pretextual Bases of Mental Disability Law. New England Journal on Criminal and Civil Confinement, 20, 369-382.

Perlin, M. L. (2012). “Justice's Beautiful Face”: Bob Sadoff and the Redemptive Promise of Therapeutic Jurisprudence. Journal of Psychiatry and Law, 40, 265-292. https://doi.org/10.2139/ssrn.2002815

Perlin, M. L. (2013). “The Judge, He Cast His Robe Aside”: Mental Health Courts, Dignity and Due Process. Mental Health Law and Policy Journal, 3, 1-28.

Perlin, M. L. (2018). "Changing of the Guards": David Wexler, Therapeutic Jurisprudence, and the Transformation of Legal Scholarship. International Journal of Law and Psychiatry, 63, 3-7. https://doi.org/10.1016/j.ijlp.2018.07.001

Perlin, M. L., Gould, K. K., \& Dorfman, D. A. (1995). Therapeutic Jurisprudence and the Civil Rights of Institutionalized Mentally Disabled Persons: Hopeless Oxymoron or Path to Redemption? Psychology, Public Policy, and Law, 1, 80-119. https://doi.org/10.1037//1076-8971.1.1.80

Petrucci, C. (2002). Respect as a Component in the Judge-Defendant Interaction in a Specialized Domestic Violence Court that Utilizes Therapeutic Jurisprudence. Criminal Law Bulletin, 28, 263-295.

Refugee Action (2018). Tipping the Scales: Access to Justice in the Asylum System. London: Refugee Action.

Refugee Council and Oxfam (2018). Safe But Not Settled: The Impact of Family Separation on Refugees in the UK.

https://policy-practice.oxfam.org.uk/publications/safe-but-not-settled-the-impact-of-fa mily-separation-on-refugees-in-the-uk-620409 
Schumm, J. A., Stines, L. R., Hobfoll, S. E., \& Jackson, A. P. (2005). The Double Barreled Burden of Child Abuse and Current Stressful Circumstances on Adult Women: The Kindling Effect of Early Traumatic Experience. Journal of Traumatic Stress, 18, 467-476. https://doi.org/10.1002/jts.20054

Scottish Refugee Council (2010). “One Day We Will Be Reunited” Experiences of Refugee Family Reunion in the UK. Scottishrefugeecouncil.org.uk.

Settle, M. (2018). SNP MP Angus Brendan MacNeil Makes Parliamentary Bid to End “Grievous Injustice” for Syrian Refugees. The Sunday Herald.

https://www.heraldscotland.com/news/16090953.snp-mp-angus-brendan-macneil-mak es-parliamentary-bid-to-end-grievous-injustice-for-syrian-refugees/

Silver, M. A. (1999). Emotional Intelligence and Legal Education. Psychology, Public Policy, and Law, 5, 1173-1203. https://doi.org/10.1037/1076-8971.5.4.1173

Sneath, G. R. (1985). Case Note: The Purposive Approach. Statute Law Review, 6, 116. https://doi.org/10.1093/slr/6.1.175

Staver, A. (2008). Family Reunification: A Right for Forced Migrants? Refugee Studies Centre Working Paper Series 51.

Stolle, D. P., \& Wexler, D. B. (1997). Therapeutic Jurisprudence and Preventive Law: A Combined Concentration to Invigorate the Everyday Practice of Law. Arizona Law Review, 39, 25-33.

Stolle, D. P., Wexler, D. B., \& Winick, B. J. (2000). Practicing Therapeutic Jurisprudence. Durham, NC: Carolina Academic Press.

Stotz, S. J., Elbert, T., Müeller, V., \& Schauer, M. (2015). The Relationship between Trauma, Shame, and Guilt: Findings from a Community-Based Study of Refugee Minors in Germany. European Journal of Psychotraumatology, 6, Article ID: 25863. https://doi.org/10.3402/ejpt.v6.25863

The Right Honourable the Lord Woolf (1996). Access to Justice Final Report. http://webarchive.nationalarchives.gov.uk/20060213205513/http://www.dca.gov.uk/civi 1/final/contents.htm

Tyler, T. R., \& Bies, R. J. (1990). Beyond Formal Procedures: The Interpersonal Context of Procedural Justice. In J. S. Carroll (Ed.), Applied Social Psychology and Organizational Settings (pp. 77-98). Hillsdale, NJ: Lawrence Erlbaum Associates. https://doi.org/10.4324/9781315728377-4

UNICEF United Kingdom (2016). For Every Child in Danger. The Refuge of the Family: How the UK Government Can Help Children Fleeing Danger Reach the Safety of Family.

https://downloads.unicef.org.uk/wp-content/uploads/2017/09/Unicef TheRefugeOfFa mily briefing.pdf

van Bueren, G. (1995). The International Protection of Family Members' Rights as the 21st Century Approaches. Human Rights Quarterly, 17, 734-735. https://doi.org/10.1353/hrq.1995.0040

Walshaw, G. (2014). Concurrent Legal Interpretation versus Moderate Intentionalism. Statute Law Review, 35, 244-260. https://doi.org/10.1093/slr/hmt025

Wexler, D. B. (1999). Therapeutic Jurisprudence: An Overview. Public Lecture Given at the Thomas Cooley Law Review Disabilities Law Symposium, Para 41.

Wexler, D. B. (2005). Therapeutic Jurisprudence and the Rehabilitative Role of the Criminal Defense Lawyer. St. Thomas Law Review, 17, 743-774.

Wexler, D. B. (2008). Rehabilitating Lawyers: Principles of Therapeutic Jurisprudence for 
Criminal Law Practice. Durham, NC: Carolina Academic Press.

Wexler, D. B. (2011a). From Theory to Practice and Back Again in Therapeutic Jurisprudence: Now Comes the Hard Part. Monash University Law Review, 37, 33-42.

Wexler, D. B. (2011b). Therapeutic Jurisprudence, Criminal Law Practice, and Relation-Centered Lawyering. Chapman Journal of Criminal Justice, 2, 93-100. https://doi.org/10.2139/ssrn.1456463

Wexler, D. B. (2013). Getting and Giving: What Therapeutic Jurisprudence Can Get from and Give to Positive Criminology. Phoenix Law Review, 6, 907-915. https://doi.org/10.2139/ssrn.2220509

Wexler, D. B. (2014a). Moving Forward on Mainstreaming Therapeutic Jurisprudence: An Ongoing Process to Facilitate the Therapeutic Design and Application of the Law. Therapeutic Jurisprudence (Paper 6).

https://papers.ssrn.com/sol3/papers.cfm?abstract id=2564613

Wexler, D. B. (2014b). New Wine in New Bottles: The Need to Sketch a Therapeutic Jurisprudence "Code" of Proposed Criminal Processes and Practices (p. 470). Arizona Legal Studies Discussion Paper No. 12-16.

Wexler, D. B., \& Winick, B. J. (1991). Essays in Therapeutic Jurisprudence. Durham, NC: Carolina Academic Press.

Wexler, D. B., \& Winick, B. J. (1996). Law in a Therapeutic Key: Developments in Therapeutic Jurisprudence. Durham, NC: Carolina Academic Press.

Wexler, D. B., \& Winick, B. J. (2006). The Use of Therapeutic Jurisprudence in Law School Clinical Education: Transforming the Criminal Law. Clinical Law Review, 13, 605-632.

Winick, B. J. (2000). Therapeutic Jurisprudence and the Role of Counsel in Litigation. California Western Law Review, 37, 105-120.

Winick, B. J., \& Wexler, D. B. (2003). Judging in a Therapeutic Key, Therapeutic Jurisprudence and the Courts. Durham, NC: Carolina Academic Press.

Yoshikawa, H., Godfrey, E. B., \& Rivera, A. C. (2008). Access to Institutional Resources as a Measure of Social Exclusion: Relations with Family Process and Cognitive Development in the Context of Immigration. New Directions for Child and Adolescent Development, 121, 63-86. https://doi.org/10.1002/cd.223 